\title{
Investigation of SHOX Gene Mutations in Turkish Patients with Idiopathic Short Stature
}

\author{
Kenan Delil1* , Halil Gürhan Karabullut2, Bülent Hacıhamdioğlu3, Zeynep Şıklar4, Merih Berberoğlu4, \\ Gönül Öçal4, Ajlan Tükün2, Hatice Ilgın Ruhi2 \\ ${ }^{1}$ Marmara University Faculty of Medicine, Department of Medical Genetics, Istanbul, Turkey \\ ${ }^{*}$ Near East University Faculty of Medicine, Department of Medical Genetics, Nicosia, North Cyprus \\ ${ }^{2}$ Ankara University Faculty of Medicine, Department of Medical Genetics, Ankara, Turkey \\ ${ }^{3}$ Süleymaniye Maternity Training and Research Hospital, Clinic of Pediatric Endocrinology, Istanbul, Turkey \\ ${ }^{4}$ Ankara University Faculty of Medicine, Department of Pediatric Endocrinology, Ankara, Turkey
}

\section{WHAT IS ALREADY KNOWN ON THIS TOPIC?}

The frequency of mutations in the short stature homeobox (SHOX) gene in patients with idiopathic short stature ranges widely, depending mostly on the mutation detection technique and inclusion criteria.

\section{ABSTRACT}

Objective: The frequency of mutations in the short stature homeobox (SHOX) gene in patients with idiopathic short stature (ISS) ranges widely, depending mostly on the mutation detection technique and inclusion criteria. We present phenotypic and genotypic data on 38 Turkish patients with ISS and the distinctive features of 1 patient with a SHOX deletion.

Methods: Microsatellite markers (MSMs) DXYS10092 (GA repeats) and DXYS10093 (CT repeats) were used to select patients for fluorescent in situ hybridisation (FISH) analysis and to screen for deletions in the SHOXgene. The FISH analysis was applied to patients homozygous for at least one MSM. A Sanger sequencing analysis was performed on patients with no deletions according to FISH to investigate point mutations in the SHOX gene.

Results: One patient $(2.6 \%)$ had a SHOX mutation

Conclusion: Although the number of cases was limited and the mutation analysis techniques we used cannot detect all mutations, our findings emphasize the importance of the difference in arm span and height when selecting patients for SHOX gene testing.

Keywords: Idiopathic short stature, SHOX gene, pseudoautosomal region 1, height, arm span-height difference

Conflict of interest: None declared

Received: 12.08 .2015

Accepted: 20.12 .2015

\section{WHAT THIS STUDY ADDS?}

Short children should be carefully investigated with respect to these mutations, even if they have only mildly disproportionate stature 


\section{Introduction}

Idiopathic short stature (ISS) is defined as a condition where a person's height is more than two standard deviations (SDs) below the average height for a specific age, gender, and population with no other systemic, endocrine, nutritional, or chromosomal abnormalities, nor a history of intrauterine growth retardation and low weight for gestational age $(1,2)$. ISS excludes other identifiable conditions not based on positive specific signs of ISS.

Height has a high degree of heritability and is a polygenic quantitative trait that shows complex and monogenic Mendelian inheritance patterns (3). One study reported that hundreds of variants clustered in specific genomic loci play roles in the human height trait (4). A clearly relevant gene that strongly affects height is the short stature homeobox (SHOX) gene, mapped to pseudoautosomal region 1 (PAR1) of the $X$ and $Y$ chromosomes. The SHOX gene has been reported to cause ISS and the short stature seen in patients with Turner's syndrome, Leri-Weill dyschondrosteosis, and Langer mesomelic dysplasia $(5,6,7,8)$. A high recombination rate in PAR1 is associated with mandatory crossover between the $X$ and $Y$ chromosomes during meiosis $(9,10,11)$. All 24 genes in the PAR1 region escape $X$ inactivation (12). As a result, all genes located in the PAR1 region have two functional copies in humans and show a pseudoautosomal inheritance pattern $(10,13)$. The only gene in the PAR1 region clearly associated with a disease is SHOX (14).

The frequency of mutations in the SHOX gene in patients with ISS varies widely, depending mainly on the mutation detection technique and inclusion criteria. In one study, approximately $2.4 \%$ of a large cohort of patients with ISS had SHOX mutations, of which $80 \%$ were complete gene deletions (15). Stuppia et al (16) reported a $12.5 \%$ frequency of SHOX mutations in 56 patients with ISS.

In this study, we evaluated the frequency of mutations in the SHOX gene in patients with ISS and discussed the distinctive clinical and radiological features of patients with such mutations.

\section{Methods}

The study was approved by the Ethics Committee of the Ankara University Faculty of Medicine. Written informed consent was obtained from all patients and their legal guardians. In all, 38 patients (34 females and 4 males; mean age, 11.84 years; range, 6.5-17 years) were included in the study. We used the following criteria based on the definition of ISS: height <-2 SD of the mean height for a given age, sex, and population group; normal karyotype (for girls); no evidence of chronic disease (e.g., chronic renal failure, chronic anaemia, celiac disease, malabsorption, malnutrition, chronic hepatic disease, chronic infectious disease, or congestive heart failure); no growth hormone $(\mathrm{GH})$ deficiency and/or $\mathrm{GH}$ resistance based on the routine provocation test (peak $\mathrm{GH}>10 \mathrm{ng} / \mathrm{mL}$ ) and normal insulin-like growth factor-1 level; no history of low birth weight; and no apparent skeletal disease.

The clinical assessment included measurements of height, weight, and sitting height, as well as the lengths of the upper segment (US), lower segment (LS), forearm, upper arm, hands, and feet. Furthermore, the degree of short stature, US/LS ratio, difference between arm span and height, assessed body proportions, extremities/trunk ratio (ETR; sum of leg length and arm span divided by sitting height), relative body mass index (RBMI), and the presence of additional features (e.g., appearance of muscular hypertrophy, cubitus valgus, forearm bowing) were evaluated.

\section{Mutation Analysis}

Genomic DNA was extracted from $1 \mathrm{~mL}$ peripheral blood using the Magna Pure LC instrument (Roche Applied Science, Manheim, Germany). We used an approach similar to the study of Chen et al (17) in which microsatellite markers (MSMs) were used to select patients for multiplex ligation-dependent probe amplification (MLPA) analysis to screen deletions in the SHOX gene. We used DXYS10092 (GA repeats) and DXYS10093 (CT repeats) to select patients for fluorescent in situ hybridisation (FISH) analysis to screen for SHOX gene deletions (Figure 1). Benito-Sanz et al (18) reported heterozygosity values of 0.96 and 0.69 for DXYS10092 and DXYS10093, respectively, and the repeat ranges were 18 and 14, respectively. Both MSMs were amplified by polymerase chain reaction and analysed on $8 \%$ polyacrylamide gels (see Supplementary Material).

The FISH analysis was applied to patients homozygous for at least one MSM using lymphocyte metaphase spreads and the Aquarius SHOX probe (cat no: LPU 025; Cytocell, Cambridge, UK).

\begin{tabular}{l}
\hline Supplementary Material \\
\hline We used 100 ng genomic DNA, 20 pmol DXYS10092 (F/R: TTC GTG ACA \\
AAG GCC TTT GC/CTA CAA GTC CTA GTA CCT AC) and DXYS10093 \\
(F/R: GCC CGT GAT CCC AGT ACT G/CAA CTT CCT TGG AAA TCT TC) \\
primers, 2 U DNA polymerase, 10 pmol dNTP, and 75 mM MgCl2 to \\
amplify each microsatellite marker. \\
SHOX Gene Sanger Sequencing: Exons 2, 3, 4, 5, and 6a and their \\
exon-intron junction sites were amplified using 100 ng genomic DNA, \\
20 pmol of each of the appropriate primers, 2 U DNA polymerase, 10 \\
pmol dNTP, and 75 mM MgCI2. The following primer sets were used: \\
exon 2-F/R: CGC GGG GAG ACG CGC GCA TCC/GGC GGC GAA CCC \\
CAG GAG GGC, exon 3-F/R: GCC ACG TTG CGC AAA ACC TC/CCC GAG \\
GAC CAG GCG ATG, exon 4-5-F/R: GGG AGG CTG GGC TGG GTT C/GGA \\
AGG GAG CAG CAG GTC C, exon 6a-F/R: GTC CCC ATC CTG CGC CCT \\
CAC CC/GCG \\
CGG AGC CCG GGA GTC CG. The ABI 3130 Genetic Analyser (Applied \\
Biosystems, Foster City, CA, USA) instrument, SeqScape ver. 2.7 \\
(Applied Biosystems) and Sequencing Analysis ver. 5.1 (Applied \\
Biosystems) software were used for the sequencing analysis. \\
\hline
\end{tabular}


Sanger sequencing was applied to patients with no deletions detected by the FISH analysis to investigate point mutations in exons 2, 3, 4, 5, and 6a and their exon-intron junction sites in the SHOX gene (see Supplementary Material).

\section{Results}

In all, 36 index cases and an additional two children (patient 2 was a monozygotic twin brother of patient 1, and patient 34 was a sister of patient 33) were evaluated. All patient heights were $<-2$ SD (Figure 2). Mean height SD was $-2.76 \pm 0.46$. Height measurements and additional anthropometric data are shown in Figure 2 and Table 1.

One patient (2.6\%, patient 12) had a SHOX deletion detected by FISH analysis (Figure 3). Patient 12 was an 11.5-year-old girl. She had a sister and two brothers with normal height, and her parents were first cousins. Her mother's height was $153 \mathrm{~cm}$ and the father's height was $178 \mathrm{~cm}$. The mother's SHOX FISH analysis was normal. Patient 12's main clinical findings were short stature (height, $137 \mathrm{~cm}$; -2.02 SD), disproportionate body measurements (arm span/ height difference: $-7,<-2$ SD), obesity (RBMI, 126.1\%), short forearms, cubitus valgus, muscular hypertrophy, genu valgus, micrognatia, high palate, and bilateral epicanthus. Hand and

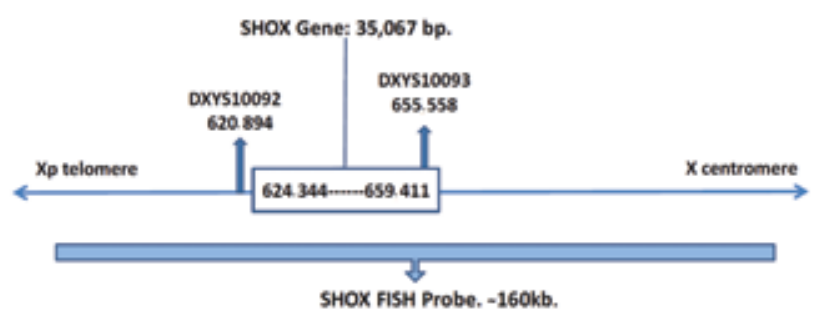

Figure 1. Schematic presentation of SHOX gene, SHOX fluorescent in situ hybridisation probe, and microsatellite markers DXYS10092 and DXYS10093 (according to Human GenomeAssembly GRCh38). FISH: fluorescent in situ hybridisation forearm radiography of the patient showed minimal bowing and mild wedging of the radius (Figure 4).

\section{Discussion}

$\mathrm{GH}$ treatment is quite effective for patients with ISS and a mutation in the SHOX gene (19). Thus, it is important to demonstrate genetic aetiology in these cases. The frequency of mutations in the SHOX gene in patients with ISS is $2-15 \%$ $(15,16,20,21,22,23)$. According to our results, this frequency was $2.6 \%$ in children with ISS.

Rappold et al (15) screened intragenic mutations using single-strand conformation polymorphism analysis in 900 patients followed by sequencing of 750 patients and detected 3 patients $(0.4 \%)$ with functional mutations. They also analysed complete gene deletions using $\mathrm{FISH}$ in 150 patients and detected 3 patients (2\%) with deletions. Another study on 56 patients with ISS reported a $12.5 \%(n=7)$ frequency of SHOX mutations (16). Jorge et al (21) reported a rate of $3.2 \%(2 / 63$ patients with ISS). A large study that included 1534 patients with ISS reported a rate of $2.2 \% \quad(n=34)(22)$. This wide range is mainly due to the mutation detection technique and the case inclusion criteria. Our results are compatible with the findings in these studies.

The clinical expression of SHOX deficiency is highly variable, as short stature is frequently nonspecific in preschool children. SHOX deficiency is more severe in females than males. Young children with SHOX deficiency may not have any specific clinical findings, but the phenotype usually becomes more pronounced with age, and characteristic signs appear over time $(21,24,25)$. The most prominent features besides short stature are a Madelung deformity, short fourth and fifth metacarpals, high arched palate, increased carrying angle of the elbow, scoliosis, and micrognathia.

Rappold et al (22) investigated the presence of SHOX defects in a large cohort of 1608 children with short stature. The mean SD in height was not different between the participants

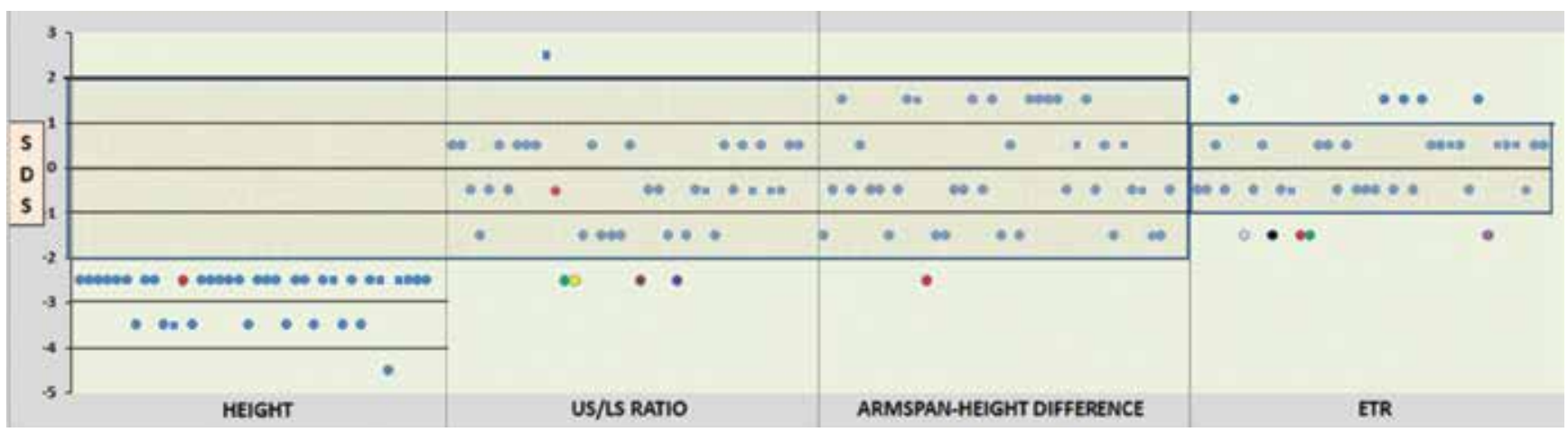

Figure 2. Height, upper segment/lower segment ratio, arm span-height difference and extremities-trunk ratio representations together with standard deviation score for all patients. Males are illustrated by square, whereas females by round. Patients lined up in order to patient number from left to right. Grey colour for P6, black for P9, red for P12, green for P13, yellow for P14, brown for P21, purple for P25, pink for P32. US: upper segment, LS: lower segment, ETR: extremities-trunk ratio 
with short stature with or without identified defects in the SHOX gene in that study. The authors created an evidencebased scoring system based on the clinical features of 68 patients with SHOX defects to identify the most appropriate children for testing. They concluded that some clinical findings were useful as clues to distinguish patients with a SHOX mutation among patients with short stature and that the presence of any combination of reduced arm span/height ratio, increased sitting height/height ratio, above average body mass index (BMI), a Madelung deformity, cubitus valgus, short or bowed forearms, dislocation of the ulna at the elbow, or muscular hypertrophy should prompt the clinician to conduct a molecular analysis for the SHOX gene. An increased sitting height/height ratio, above average BMI, cubitus valgus, short forearms, and muscular hypertrophy were noted in our case with an SHOX gene deletion.

Binder et al (24) used ETR to select patients more likely to have a SHOX mutation. They suggested that screening for SHOX mutations should be limited to patients whose ETR is $<1.95+1 / 2$ height $(\mathrm{m})$ and close inspection of a

Table 1. Evaluation of anthropometric measurements in the patients

\begin{tabular}{|l|l|l|}
\hline Features & $\begin{array}{l}\text { Mean } \mathbf{(} \pm \mathbf{S D}) \\
\mathbf{n}=38\end{array}$ & $\begin{array}{l}\text { (Minimum/ } \\
\text { Maximum) }\end{array}$ \\
\hline Chronological age (year) & $11.84( \pm 1.99)$ & $6.5 / 17$ \\
\hline Height (cm) & $132.28( \pm 9.6)$ & $104.5 / 154$ \\
\hline Height SDs & $-2.76( \pm 0.46)$ & $(-4.05) /(-2.01)$ \\
\hline BMI (kg/m2) & $16.44( \pm 3.7)$ & $12.03 / 25.01$ \\
\hline RBMI (\%) & $85.61( \pm 15.69)$ & $64.24 / 134.39$ \\
\hline Maternal height (cm) & $154.16( \pm 6.44)$ & $141 / 167$ \\
\hline Paternal height (cm) & $166.32( \pm 6.55)$ & $155 / 185$ \\
\hline Target height SDS & $-1.15( \pm 0.97)$ & $(-3.46) / 0.75$ \\
\hline Height SDS-Target height SDS & $-1.62( \pm 1.02)$ & $(-3.78) / 0.66$ \\
\hline Arm span (cm) & $131.79( \pm 11.01)$ & $98.5 / 160$ \\
\hline Arm span-Height difference (cm) & $-0.49( \pm 3.7)$ & $(-7) / 6$ \\
\hline Sitting height (cm) & $70.11( \pm 5.37)$ & $57 / 81$ \\
\hline Upper segment (cm) & $63.63( \pm 5.13)$ & $52.5 / 79$ \\
\hline Lower segment (cm) & $68.64( \pm 5.41)$ & $52 / 76$ \\
\hline Upper/Lower ratio & $0.93( \pm 0.06)$ & $0.77 / 1.07$ \\
\hline Extremity/Trunk ratio & $2.76( \pm 0.12)$ & $2.52 / 3.06$ \\
\hline Arm (cm) & $27.09( \pm 2.57)$ & $19.5 / 32$ \\
\hline Forearm (cm) & $20.54( \pm 1.76)$ & $15 / 25$ \\
\hline Hand (cm) & $15.34( \pm 1.36)$ & $11.5 / 18$ \\
\hline Feet (cm) & $21.37( \pm 1.7)$ & $17 / 25$ \\
\hline $\begin{array}{l}\text { SDS: standart deviation score, SD: standart deviation, RBMl: relative body mass } \\
\text { index, BMl: body mass index }\end{array}$ & & \\
\hline
\end{tabular}

hand radiograph to detect the main characteristics of SHOX deficiency (pyramidalisation of the carpal row, radiolucency of the distal radius at the ulnar border, and triangularisation of the distal radius) in school-age children. Jorge et al (21) confirmed the usefulness of this approach and recommended using the sitting height/height ratio because it is easier to use than ETR. Our results suggest that the ETR and the difference in arm span and height are useful parameters. The US/LS ratio was not reliable alone, as this parameter was normal in our patients (Figure 2).

A radiographic examination of a patient with an $\mathrm{SHOX}$ gene mutation may demonstrate abnormal carpal wedging, triangularisation of the distal radial epiphysis, radial lucency, shortening of fourth and fifth metacarpals, and radial bowing (26). We did not detect any striking findings on a radiograph of the left hand in our patient, and she had only minimal bowing of the radius and mild wedging. It is not possible to analyse every child with ISS for a SHOX gene mutation because of its low incidence. Phenotypic variation in short children can affect the decision to perform a genetic analysis. Beyond the typical dysmorphic signs, a positive family history, careful anthropometric measurements and an x-ray evaluation of the hand and wrist can be used to support this decision.

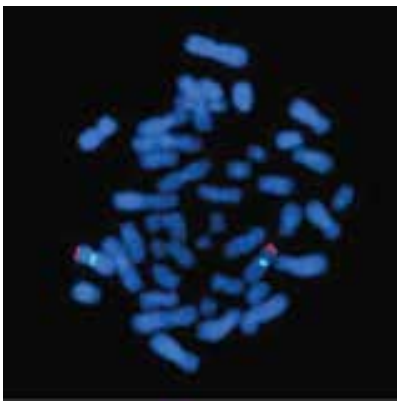

a

Figure 3. (a and b) Fluorescent in situ hybridisation images from $\mathrm{P} 12$ and P20. P20 showed two blue and two red signals meaning normal female. P12 showed two blue but 1 red signal meaning SHOX gene deletion (right). Probe specification: SHOX probe; Xp22.33/Yp11.2, (Red)/DYZ1 probe; Yq12, (Green) and DXZ1 probe; Xp11.1-q11.1, (Blue)

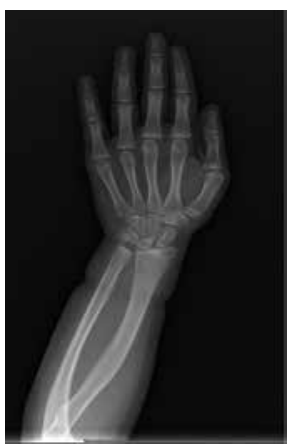

Figure 4. Hand and forearm radiography of the patient with SHOX deletion (P12) showing minimal bowing and mild wedging of the radius 
Although we had a limited number of cases and the mutation analysis techniques used could not detect all mutations, our findings emphasize the importance of the difference between arm span and height when selecting patients for SHOX gene testing. Nevertheless, more extensive studies with larger groups of patients and a wider range of mutation screening techniques are needed.

Deletions are the most frequently detected SHOX gene mutations (15). In our study, we first performed MSM and then a FISH analysis to screen for SHOX gene deletions. Funari et al (27) suggested that MLPA should be the first molecular method used to screen for SHOX gene deletions. We also suggest using MLPA first because SHOX deletions are highly heterogeneous, so numerous MSM loci may need to be studied, and MLPA can detect smaller deletions than $\mathrm{FISH}$.

In summary, our patient with a SHOX mutation had no obvious findings associated with such a gene deletion. She had a disproportionate body, which could easily go unnoticed, but she had no obvious Madelung deformity.

In conclusion, we detected an SHOX gene deletion in 1 of 38 children with ISS. Short children should be carefully investigated with respect to these mutations, even if they have only mildly disproportionate stature.

\section{Ethics}

Ethics Committee Approval: The study was approved by the Ethics Committee of the Ankara University Faculty of Medicine Ankara University, 04/10/2010, Informed Consent: It was taken.

Peer-review: External peer-reviewed.

\section{Authorship Contributions}

Concept: Kenan Delil, Halil Gürhan Karabulut, Zeynep Şıklar, Merih Berberoğlu, Gönül Öçal, Ajlan Tükün, Hatice Ilgın Ruhi, Design: Kenan Delil, Halil Gürhan Karabulut, Zeynep Şıklar, Merih Berberoğlu, Gönül Öçal, Ajlan Tükün, Hatice Ilgın Ruhi, Data Collection and/or Processing: Kenan Delil, Halil Gürhan Karabulut, Bülent Hacıhamdioğlu, Zeynep Şıklar, Ajlan Tükün, Analysis and/or Interpretation: Kenan Delil, Halil Gürhan Karabulut, Bülent Hacıhamdioğlu, Zeynep Şıklar, Literature Research: Kenan Delil, Halil Gürhan Karabulut, Writing: Kenan Delil, Halil Gürhan Karabulut, Bülent Hacıhamdioğlu, Zeynep Şıklar, Ajlan Tükün, Hatice Ilgın Ruhi.

Financial Disclosure: The authors declared that this study received no financial support.

\section{References}

1. Ranke MB. Towards a consensus on the definition of idiopathic short stature. Horm Res 1996;45(Suppl 2):64-66.

2. Cohen $P$, Rogol $A D$, Deal $C L$, Saenger $P$, Reiter $E O$, Ross JL, Chernausek SD, Savage MO, Wit JM; 2007 ISS Consensus Workshop participants. Consensus statement on the diagnosis and treatment of children with idiopathic short stature: a summary of the Growth Hormone Research Society, the Lawson Wilkins Pediatric Endocrine Society, and the European Society for Paediatric Endocrinology Workshop. J Clin Endocrinol Metab 2008;93:4210-4217. Epub 2008 Sep 9

3. Durand C, Rappold GA. Height matters-from monogenic disorders to normal variation. Nat Rev Endocrinol 2013;9:171177. Epub 2013 Jan 22

4. Lango Allen $\mathrm{H}$, Estrada K, Lettre G, Berndt SI, Weedon MN, Rivadeneira F, Willer CJ, Jackson AU, Vedantam S, Raychaudhuri S, Ferreira T, Wood AR, Weyant RJ, Segrè AV, Speliotes EK, Wheeler E, Soranzo N, Park JH, Yang J, Gudbjartsson D, Heard-Costa NL, Randall JC, Qi L, Vernon Smith A, Mägi R, Pastinen T, Liang $L$, Heid IM, Luan J, Thorleifsson G, Winkler TW, Goddard ME, Sin Lo $\mathrm{K}$, Palmer C, Workalemahu T, Aulchenko YS, Johansson A, Zillikens MC, Feitosa MF, Esko T, Johnson T, Ketkar S, Kraft P, Mangino M, Prokopenko I, Absher D, Albrecht E, Ernst F, Glazer NL, Hayward C, Hottenga JJ, Jacobs KB, Knowles JW, Kutalik Z, Monda KL, Polasek O, Preuss M, Rayner NW, Robertson NR, Steinthorsdottir V, Tyrer JP, Voight BF, Wiklund F, Xu J, Zhao JH, Nyholt DR, Pellikka N, Perola M, Perry JR, Surakka I, Tammesoo ML, Altmaier EL, Amin N, Aspelund T, Bhangale T, Boucher G, Chasman DI, Chen C, Coin L, Cooper MN, Dixon AL, Gibson Q, Grundberg E, Hao K, Juhani Junttila M, Kaplan LM, Kettunen J, König IR, Kwan T, Lawrence RW, Levinson DF, Lorentzon M, McKnight B, Morris AP, Müller M, Suh Ngwa J, Purcell S, Rafelt S, Salem RM, Salvi E, Sanna S, Shi J, Sovio U, Thompson JR, Turchin MC, Vandenput L, Verlaan DJ, Vitart V, White CC, Ziegler A, Almgren $P$, Balmforth $A J$, Campbell $H$, Citterio L, De Grandi A, Dominiczak A, Duan J, Elliott P, Elosua R, Eriksson JG, Freimer NB, Geus EJ, Glorioso N, Haiqing S, Hartikainen AL, Havulinna AS, Hicks AA, Hui J, Igl W, Illig T, Jula A, Kajantie E, Kilpeläinen TO, Koiranen M, Kolcic I, Koskinen S, Kovacs P, Laitinen J, Liu J, Lokki ML, Marusic A, Maschio A, Meitinger T, Mulas A, Paré G, Parker AN, Peden JF, Petersmann A, Pichler I, Pietiläinen $\mathrm{KH}$, Pouta $A$, Ridderstråle $M$, Rotter JI, Sambrook JG, Sanders AR, Schmidt CO, Sinisalo J, Smit $J H$, Stringham HM, Bragi Walters G, Widen E, Wild SH, Willemsen $G$, Zagato L, Zgaga L, Zitting P, Alavere $H$, Farrall M, McArdle WL, Nelis M, Peters MJ, Ripatti S, van Meurs JB, Aben KK, Ardlie KG, Beckmann JS, Beilby JP, Bergman RN, Bergmann S, Collins FS, Cusi D, den Heijer M, Eiriksdottir G, Gejman PV, Hall AS, Hamsten A, Huikuri HV, Iribarren C, Kähönen M, Kaprio J, Kathiresan S, Kiemeney L, Kocher T, Launer LJ, Lehtimäki T, Melander O, Mosley TH Jr, Musk AW, Nieminen MS, O'Donnell CJ, Ohlsson C, Oostra B, Palmer LJ, Raitakari O, Ridker PM, Rioux JD, Rissanen A, Rivolta C, Schunkert $H$, Shuldiner AR, Siscovick DS, Stumvoll M, Tönjes A, Tuomilehto J, van Ommen GJ, Viikari J, Heath AC, Martin NG, Montgomery GW, Province MA, Kayser M, Arnold AM, Atwood LD, Boerwinkle E, Chanock SJ, Deloukas P, Gieger C, Grönberg $H$, Hall P, Hattersley AT, Hengstenberg $C$, Hoffman W, Lathrop GM, Salomaa V, Schreiber S, Uda M, Waterworth D, Wright AF, Assimes TL, Barroso I, Hofman A, Mohlke KL, Boomsma DI, Caulfield MJ, Cupples LA, Erdmann J, Fox CS, Gudnason V, Gyllensten U, Harris TB, Hayes RB, Jarvelin MR, Mooser V, Munroe PB, Ouwehand WH, Penninx BW, Pramstaller PP, Quertermous T, Rudan I, Samani NJ, Spector TD, Völzke H, Watkins H, Wilson JF, Groop LC, Haritunians T, Hu FB, Kaplan RC, Metspalu A, North KE, Schlessinger D, Wareham NJ, Hunter DJ, O'Connell JR, Strachan DP, Wichmann HE, Borecki IB, van Duijn CM, Schadt EE, 
Thorsteinsdottir U, Peltonen L, Uitterlinden AG, Visscher PM, Chatterjee N, Loos RJ, Boehnke M, McCarthy MI, Ingelsson E, Lindgren CM, Abecasis GR, Stefansson K, Frayling TM, Hirschhorn JN. Hundreds of variants clustered in genomic loci and biological pathways affect human height. Nature 2010;467:832-838. Epub 2010 Sep 29

5. Rao E, Weiss B, Fukami M, Rump A, Niesler B, Mertz A, Muroya K, Binder G, Kirsch S, Winkelmann M, Nordsiek G, Heinrich $U$, Breuning $M H$, Ranke MB, Rosenthal A, Ogata T, Rappold GA. Pseudoautosomal deletions encompassing a novel homeobox gene cause growth failure in idiopathic short stature and Turner syndrome. Nat Genet 1997;16:5463.

6. Ellison JW, Wardak Z, Young MF, Gehron Robey P, LaigWebster M, Chiong W. PHOG, a candidate gene for involvement in the short stature of Turner syndrome. Hum Mol Genet 1997;6:1341-1347.

7. Shears DJ, Vassal HJ, Goodman FR, Palmer RW, Reardon W, Superti-Furga A, Scambler PJ, Winter RM. Mutation and deletion of the pseudoautosomal gene SHOX cause LeriWeill dyschondrosteosis. Nat Genet 1998;19:70-73.

8. Belin V, Cusin V, Viot G, Girlich D, Toutain A, Moncla A, Vekemans $M$, Le Merrer M, Munnich A, Cormier-Daire V. SHOX mutations in dyschondrosteosis (Leri-Weill syndrome). Nat Genet 1998;19:67-69.

9. Burgoyne PS. Genetic homology and crossing over in the $X$ and $Y$ chromosomes of Mammals. Hum Genet 1982;61:8590 .

10. Rouyer F, Simmler MC, Johnsson C, Vergnaud G, Cooke $\mathrm{HJ}$, Weissenbach J. A gradient of sex linkage in the pseudoautosomal region of the human sex chromosomes. Nature 1986;319:291-295.

11. Page DC, Bieker K, Brown LG, Hinton S, Leppert M, Lalouel JM, Lathrop M, Nystrom-Lahti $M$, de la Chapelle A, White R. Linkage, physical mapping, and DNA sequence analysis of pseudoautosomal loci on the human $X$ and $Y$ chromosomes. Genomics 1987;1:243-256.

12. Ciccodicola A, D'Esposito M, Esposito T, Gianfrancesco $F$ Migliaccio C, Miano MG, Matarazzo MR, Vacca M, Franzè A, Cuccurese M, Cocchia M, Curci A, Terracciano A, Torino A, Cocchia S, Mercadante G, Pannone E, Archidiacono $N$, Rocchi M, Schlessinger D, D'Urso M. Differentially regulated and evolved genes in the fully sequenced $\mathrm{Xq} / \mathrm{Yq}$ pseudoautosomal region. Hum Mol Genet 2000;9:395-401.

13. Cooke HJ, Brown WR, Rappold GA. Hypervariable telomeric sequences from the human sex chromosomes are pseudoautosomal. Nature 1985;317:687-692.

14. Blaschke RJ, Rappold G. The pseudoautosomal regions, SHOX and disease. Curr Opin Genet Dev 2006;16:233-239. Epub 2006 May 2

15. Rappold GA, Fukami M, Niesler B, Schiller S, Zumkeller W, Bettendorf M, Heinrich U, Vlachopapadoupoulou E, Reinehr T, Onigata K, Ogata T. Deletions of the homeobox gene SHOX (short stature homeobox) are an important cause of growth failure in children with short stature. J Clin Endocrinol Metab 2002;87:1402-1406.

16. Stuppia L, Calabrese G, Gatta V, Pintor S, Morizio E, Fantasia D, Guanciali Franchi P, Rinaldi MM, Scarano G, Concolino D, Giannotti A, Petreschi F, Anzellotti MT, Pomilio M, Chiarelli F, Tumini S, Palka G. SHOX mutations detected by FISH and direct sequencing in patients with short stature. J Med Genet 2003;40:11.
17. Chen J, Wildhardt G, Zhong Z, Röth R, Weiss B, Steinberger D, Decker J, Blum WF, Rappold G. Enhancer deletions of the SHOX gene as a frequent cause of short stature: the essential role of a $250 \mathrm{~kb}$ downstream regulatory domain. J Med Genet 2009;46:834-839. Epub 2009 Jul 2

18. Benito-Sanz S, Thomas NS, Huber C, Gorbenko del Blanco D, Aza-Carmona M, Crolla JA, Maloney V, Rappold G, Argente J, Campos-Barros A, Cormier-Daire V, Heath KE. A novel class of Pseudoautosomal region 1 deletions downstream of $\mathrm{SHOX}$ is associated with Leri-Weill dyschondrosteosis. Am J Hum Genet 2005;77:533-544. Epub 2005 Aug 15

19. Blum WF, Crowe BJ, Quigley CA, Jung H, Cao D, Ross JL, Braun L, Rappold G; SHOX Study Group. Growth hormone is effective in treatment of short stature associated with short stature homeobox-containing gene deficiency: Twoyear results of a randomized, controlled, multicenter trial. J Clin Endocrinol Metab 2007;92:219-228. Epub 2006 Oct 17

20. Benito-Sanz S, Gorbenko del Blanco D, Huber C, Thomas NS, Aza-Carmona M, Bunyan D, Maloney V, Argente J, CormierDaire $V$, Campos-Barros A, Heath KE. Characterization of SHOX deletions in Leri-Weill dyschondrosteosis (LWD) reveals genetic heterogeneity and no recombination hotspots. Am J Hum Genet 2006;79:409-414.

21. Jorge AA, Souza SC, Nishi MY, Billerbeck AE, Libório DC, Kim CA, Arnhold IJ, Mendonca BB. SHOX mutations in idiopathic short stature and Leri-Weill dyschondrosteosis: frequency and phenotypic variability. Clin Endocrinol (Oxf) 2007;66:130135.

22. Rappold G, Blum WF, Shavrikova EP, Crowe BJ, Roeth R, Quigley CA, Ross JL, Niesler B. Genotypes and phenotypes in children with short stature: clinical indicators of SHOX haploinsufficiency. J Med Genet 2007;44:306-313. Epub 2006 Dec 20

23. Shapiro S, Klein GW, Klein ML, Wallach EJ, Fen Y, Godbold JH, Rapaport R. SHOX gene variants: growth hormone/ insulin-like growth factor-1 status and response to growth hormone treatment. Horm Res Paediatr 2015;83:26-35. Epub 2015 Jan 31

24. Binder G, Ranke MB, Martin DD. Auxology is a valuable instrument for the clinical diagnosis of SHOX haploinsufficiency in school-age children with unexplained short stature. J Clin Endocrinol Metab 2003;88:4891-4896.

25. Ross JL, Scott C Jr, Marttila P, Kowal K, Nass A, Papenhausen P, Abboudi J, Osterman L, Kushner H, Carter P, Ezaki M, Elder F, Wei F, Chen H, Zinn AR. Phenotypes Associated with SHOX Deficiency. J Clin Endocrinol Metab 2001;86:56745680 .

26. Child CJ, Kalifa G, Jones C, Ross JL, Rappold GA, Quigley CA, Zimmermann AG, Garding G, Cutler GB Jr, Blum WF Radiological Features in Patients with Short Stature Homeobox-Containing (SHOX) Gene Deficiency and Turner Syndrome before and after 2 Years of $\mathrm{GH}$ Treatment. Horm Res Paediatr 2015;84:14-25. Epub 2015 May 6

27. Funari MF, Jorge AA, Souza SC, Billerbeck AE, Arnhold $\mathrm{IJ}$, Mendonca BB, Nishi MY. Usefulness of MLPA in the detection of SHOX deletions. Eur J Med Genet 2010;53:234238. Epub 2010 Jun 9 